\title{
Implementation of innovative marketing technologies for higher efficiency of the marketing communication complex
}

\author{
Olena Syvolovska ${ }^{1 *}$, Tetiana Neskuba $^{1}$, Olena Aleksandrova ${ }^{2}$ and Olena Mkrtychyan $^{1}$ \\ ${ }^{1}$ Ukrainian State University of Railway Transport, Department of Marketing, Feierbakh Square 7, \\ 61050, Kharkiv, Ukraine \\ ${ }^{2}$ Ukrainian State University of Railway Transport, Department of Economic Theory and Law, \\ Feierbakh Square 7, 61050, Kharkiv, Ukraine
}

\begin{abstract}
The authors analyzed the basic trends in development of marketing communications in Ukraine and defined efficient innovating marketing methods, one of which is neuromarketing. The article generalizes experience in implementing neuromarketing techniques in Ukraine and all over the world, systematizes methods, technologies and tools of neuromarketing and defines the areas of usage for business activity in Ukraine. Besides, the article analyzes faults, advantages and prospects of neuromarketing development, classifies target audiences in terms of their response to neuromarketing methods and techniques. It also touches a need to implement on-line neuromarketing tools.
\end{abstract}

\section{Problem Statement}

Due to oversaturation of the infosphere, the customer is becoming more demanding and ignores any marketing techniques drawing their attention.

The product choice is based on the subconscious customer motivation. Therefore everything presented in the advertising, namely "rational arguments, attractive colors and high quality" do not increase the sales volume due to low efficiency. And in order to solve these problems innovating techniques are being integrated into the marketing communication complex thus influencing an emotional state of the customer. A simple tune and text in the Coca-Cola advertisement are an example of such technologies. Among highly effective innovative marketing techniques are neuromarketing, word-of-mouth marketing, native advertising, viral marketing and others.

A lot of experts in the field studied the scientific basis of the use of neuromarketing as an innovative and highly efficient trend in marketing activity. Among them are D. Ariely and G.S. Berns [11], G. Zaltman [6], M. Lindstrom [7], A. Traindl, [9], D. Ogilvy [14], V.C.R. Fortunato, J.V.E. Giraldi, J.H.C. de Oliverira [10], O. Zorina, K. Zybina, I. Syvolovskiy [2], M. Oklander, Yu. Gubareva [5] and A. Kislov [3]. A great number of such publications testify to the fact that development of a set of neuromarketing tools for Ukraine is demanded and needed.

\footnotetext{
* Corresponding author: alenasvl3@gmail.com
} 
In spite of their high efficiency, neuromarketing techniques are not used for business activity in Ukraine. It implies that the problem is urgent and requires investigation.

The objective of the article is systematization and generalization of global experience in using neuromarketing techniques, classification of the target audiences in terms of the impact and development of on-line neuromarketing tools.

\section{Basic material of the research}

The analysis of trends in marketing communication development in Ukraine demonstrated that the advertising market increased by $25 \%$ in 2018 . And an increase of about $27 \%$ has been forecasted for 2019. The statistical analysis of Ukraine's adverting market is given in Table $1[1]$

Table 1 Growth rates of Ukraine's advertising market [1]

\begin{tabular}{|c|c|c|c|c|c|}
\hline $\begin{array}{c}\text { Marketing } \\
\text { communication tool }\end{array}$ & $\begin{array}{c}\text { Totals of } \\
2017 \\
\text { mln hrn }\end{array}$ & $\begin{array}{c}\text { Totals of } \\
2018 \\
\text { mln hrn }\end{array}$ & $\begin{array}{c}\text { Change } \\
\text { rate of } \\
2018 \text { to } \\
2017\end{array}$ & $\begin{array}{l}\text { Forecast } \\
\text { for } 2019 \\
\text { mln hrn }\end{array}$ & $\begin{array}{c}\text { Change } \\
\text { rate of } \\
2019 \text { to } \\
2018\end{array}$ \\
\hline $\begin{array}{c}\text { TV advertising, } \\
\text { totals }\end{array}$ & 7329 & 9269 & $26 \%$ & 11526 & $24 \%$ \\
\hline Direct advertising & 6355 & 8071 & $27 \%$ & 10089 & $25 \%$ \\
\hline Sponsorship & 974 & 1198 & $23 \%$ & 1438 & $20 \%$ \\
\hline $\begin{array}{c}\text { Press advertising, } \\
\text { totals }\end{array}$ & 1355 & 1612 & $18.9 \%$ & 1843 & $14.4 \%$ \\
\hline $\begin{array}{c}\text { Radio advertising, } \\
\text { totals } \\
\end{array}$ & 480 & 578 & $20 \%$ & 715 & $24 \%$ \\
\hline National radio & 348 & 418 & $20 \%$ & 518 & $24 \%$ \\
\hline Regional radio & 47 & 54 & $15 \%$ & 65 & $20 \%$ \\
\hline Sponsorship & 85 & 106 & $25 \%$ & 133 & $25 \%$ \\
\hline $\begin{array}{c}\text { Media advertising, } \\
\text { totals }\end{array}$ & 2692 & 3493 & $30 \%$ & 4307 & $23 \%$ \\
\hline Outdoor advertising & 2263 & 2923 & $29 \%$ & 3601 & $23 \%$ \\
\hline $\begin{array}{c}\text { Transportation } \\
\text { advertising }\end{array}$ & 327 & 444 & $36 \%$ & 553 & $25 \%$ \\
\hline Indoor advertising & 102 & 127 & $24 \%$ & 152 & $20 \%$ \\
\hline $\begin{array}{c}\text { In-theatre } \\
\text { advertising }\end{array}$ & 40 & 48 & $20 \%$ & 58 & $20 \%$ \\
\hline $\begin{array}{c}\text { Internet } \\
\text { advertising }\end{array}$ & 2145 & 2520 & $17 \%$ & 3772 & $50 \%$ \\
\hline $\begin{array}{c}\text { Advertising } \\
\text { market, totals }\end{array}$ & 14041 & 17520 & $25 \%$ & 22221 & $27 \%$ \\
\hline & & & & & \\
\hline
\end{tabular}

Research [2] demonstrates that the advertising market suffers from a shift in emphasis from conventional market technologies to innovative tools, namely: neuromarketing, contextual advertising, targeted advertising, sms and SEO promotion.

All these methods are directly aimed at a targeted audience and rather popular, but the efficiency of neuromarketing accounts for $100 \%$.

The neuromarketing studies the subconscious customer response to certain stimuli. Neuromarketing appeared when it was impossible to use models of classic economic theory 
in the modern business reality. It refers to the expected utility theory of von NeumannMorgenstern described by formula (1); but it does not work today.

According to the theory, the customer has to choose an alternative of the maximum mathematical expectations. However, under risks and uncertainty, while taking decisions about the product choice, the customer tries to achieve the absolute reliability from the product without maximizing the expected utility. It is called the Allais Paradox (after the French economist Maurice Allais [3]):

$$
E U=P(W) \times U(W)
$$

EU is the expected utility of the customer choice;

$\mathrm{P}(\mathrm{W})$ is the probability of the customer choice;

$\mathrm{U}(\mathrm{W})$ is the utility of the customer choice.

Thus, market specialists could not understand what the actual motivation for a customer in terms of taking decisions was; as far as all attempts to open "the black box of awareness" with standard methods were useless, the specialists decided to soak into the customer's mind. That was the way how neuromarketing appeared.

The neuromarketing concept was developed in Harvard University in 1990. The technology is based on the model according to which the basic part of thinking activity (over $90 \%$ ), including emotions, takes place in the subconscious part located below the controlled realization level. The understanding of the fact what parts of the brain respond to certain decisions made it possible to manipulate the customer [4].

This method is called the Zaltman metaphor elicitation technique (ZMET). The founder, professor Zaltman, believed that studying gestures and other nonverbal communication forms could present considerable potential to obtain additional information. The brain processes the information subconsciously and at a high speed, and, therefore, decisions are taken subconsciously [5].

The ZMET model [6] implies the analysis of the customer behavior according to the brand images generated in the customer consciousness. It includes a set of some theme pictures for obtaining a positive emotional response, thus activating hidden images, for example, metaphors stimulating a customer choice. This model is used by Coca-Cola, GM, Nestle, P \& G.

A ZMET model provides research into the customer's subconsciousness; the next stage was implementation of techniques to research the brain.

In 2002 in Atlanta within the project "The Brighthouse Institute for Thought Sciences" the MRI scanning and EEG monitoring techniques were implemented for the first time [5]. The test patients were exposed to visual images, smells, voices, while a magnetic resonance tomography and an electroencephalograph recorded active reactions of the brain areas.

Nowadays neuromarketing evaluates reactions of organ of senses (vision, scent, touch, taste, hearing) to various stimuli (sound, light, look, image, photo, smell, touch sensibility). How it works? Martin Lindstrom, a famous neuromarkting specialist, proves that a pleasant sound accompanying a purchase increases the amount of goods purchased by $65 \%$; a pleasant taste - by $23 \%$; a pleasant smell - by $40 \%$; pleasant tactile sensing - by $26 \%$; aesthetic appearance - by $46 \%$ [7]. Such aromatic neuromarketing (odor of flowers, mostly lilies) is used in the fashion shops HugoBoss. And genuine leather flavor is in compulsory use at leather shops.

The analysis of world experience of using the neuromarketing technologies made it possible to distinguish basic ones and characterize them (Table 2).

The global business makes ample use of neuromarketing techniques. In 2016 over 180 enterprises united in the Neuromarketing Science \& Business Association. According to 
market research [8] today's neuromarketing is estimated by about $\$ 1$ billion, and up to 2025 it is going to increase up to $\$ 2.2$ billion.

Table 2. Description of the basic neuromarketing techniques.

\begin{tabular}{|l|l|}
\hline \multicolumn{1}{|c|}{$\begin{array}{c}\text { Neuromarketing tools } \\
\text { and techniques }\end{array}$} & \multicolumn{1}{|c|}{ Description } \\
\hline Facial Expressions Scanner & $\begin{array}{l}\text { Obtaining data on the responder's emotions by } \\
\text { analyzing the dynamic facial response to external } \\
\text { stimuli }\end{array}$ \\
\hline Eye-tracking & $\begin{array}{l}\text { Tracking the movement of the customer's eyes and } \\
\text { determining the areas of interest }\end{array}$ \\
\hline $\begin{array}{l}\text { Electroencephalography (EEG) } \\
\text { and topography }\end{array}$ & $\begin{array}{l}\text { Studying the processes in the cerebral cortex by } \\
\text { recording the bioelectric activity. }\end{array}$ \\
\hline $\begin{array}{l}\text { Biometrical sensors (cardiac } \\
\text { rates, breathing rates, galvanic } \\
\text { skin responses) }\end{array}$ & $\begin{array}{l}\text { Measuring changes in the physiological state, i.e. } \\
\text { cognitive, vision, auditory and somatic sensory } \\
\text { reactions. }\end{array}$ \\
\hline $\begin{array}{l}\text { Magnetic resonance imaging } \\
\text { MRI) }\end{array}$ & Monitoring brain processes \\
\hline
\end{tabular}

Leading international corporations widely use neuromarketing techniques, which is confirmed by business practices. Microsoft Corporation implements the EEG monitoring techniques to understand the reasons of excitement, satisfaction, disappointment when users interact with computers. The Frito-Lay company uses the MRI scanning techniques for determining verbal structures or symbols undesirable when addressing female customers. The ŠKODA company uses eye-tracking to study the efficiency of the video advertising CarBakers with making a Skoda Fabia cake [9].

On the other hand, neuromarketing techniques are often criticized due to lack of academic approach and its low practical value at very high costs [10]. The generalized analysis of advantages and disadvantages of neuromarketing tools is presented in Table. 3.

The analysis of global practices in usage of neuromarketing tools made it possible to define their prospective areas for Ukrainian businesses.

1. Marketing research into recording the responder's neurologic processes. Study into the customer's subconscious reactions to certain stimuli. High vividness in contrast to the conventional marketing research. The studies may lead to producing an ideal product.

Table 3. Advantages and disadvantages of neuromarketing tools.

\begin{tabular}{|l|l|}
\hline \multicolumn{1}{|c|}{ Advantages of neuromarketing tools } & \multicolumn{1}{|c|}{ Disadvantages of neuromarketing tools } \\
\hline $\begin{array}{l}\text { High quality and objectivity of the data } \\
\text { obtained in neuromarketing research }\end{array}$ & $\begin{array}{l}\text { High costs and a pressing need for qualified } \\
\text { specialists in psychiatry, neurophysiology } \\
\text { and other fields [11]. }\end{array}$ \\
\hline $\begin{array}{l}\text { High impact efficiency of neuromarketing } \\
\text { stimuli on the customer's choice, brand } \\
\text { loyalty and positive advertising perception. }\end{array}$ & $\begin{array}{l}\text { Ethical incorrectness and breach of } \\
\text { confidence [11]. For example, a scandal with } \\
\text { the use of personal data of Facebook } \\
\text { subscribers in Donald Tramp presidential } \\
\text { campaign. }\end{array}$ \\
\hline $\begin{array}{l}\text { Image data obtained through } \\
\text { neuromarketing research. }\end{array}$ & $\begin{array}{l}\text { Physiological discomfort for responders, } \\
\text { possibility to manipulate the customer } \\
\text { consciousness. }\end{array}$ \\
\hline $\begin{array}{l}\text { High speed in obtaining data and } \\
\text { processing efficiency }\end{array}$ & $\begin{array}{l}\text { Ambiguous readings of the results of } \\
\text { research due to various customer reactions to }\end{array}$ \\
\hline
\end{tabular}




\begin{tabular}{|l|l|}
\hline & stimuli \\
\hline $\begin{array}{l}\text { A clear marketing concept for a new article } \\
\text { based on the data obtained }\end{array}$ & $\begin{array}{l}\text { Complex calculation of economic efficiency } \\
\text { for neuromarketing techniques. }\end{array}$ \\
\hline
\end{tabular}

2. Branding. Creation of the basic brand truth with sensor, tactile, audio and aroma indicators which together form highly effective Net Promoter Scores (brand loyalty).

3. Marketing communication complex. Development and rollout of highly effective video and audio reels, outdoor, printed and ambient advertising, P.O.S materials, promotional production and others.

4. Internet-marketing with neurotechnologies. Creation of an online content with neuromarketing tools. For example, neuromarketing helps create webpage heat maps based on data about eye movements, basic objects of interest and other reactions through Web surfing.

5. Entertainment. It is used while producing movies, series and show programs for effective rating forecasting. For example, a spin-off of a super popular serial can be created with neuromarketing tools.

Implementation of neuromarketing techniques should obviously consider different reactions of target groups to neuromarketing technologies [12]. The problem can be solved with consideration of the results obtained in the research [4], where target audiences are classified according to impacts from neuromarketing techniques. 1. "Customers of safety". Their priorities are family, customs and stability. They respond to the product price rather than a brand; "aggressive" sellers cause them discomfort. They negatively react to bright colors, shocking behavior, loud music and emotional pictures. They should be excluded from the focus group in researching new products for young people, trend clothes, innovative technologies.

2. "Alfa people". Their choice is based on status, prestige and success. The brand is important for them, and only a very high price can be disappointing. They negatively react to the mass-market products. They should be included for the research of upscale goods.

3. "Social people". They adore bright shopping and entertainment complexes and huge supermarkets. They positively react to new products or improvements in the mass market. It is these people who must be included in such research as the focus group.

4. "Pioneers". They know much about innovations; they know what brand new product is going to enter the market and know it better than the sellers. They are ready to spend all their money for a latest model and drive the seller distracted with their questions. They form an ideal target audience for researching innovating technologies.

The advertising market statistics in Ukraine [1] proves a need to implement innovating marketing technologies via Internet, as it is Internet demonstrates the highest rates of development of trade and advertising. Therefore, there is a need to implement on-line neuromarketing methods.

Among on-line basic neuromarketing methods are:

1 The social proof effect. $70 \%$ of buyers study opinions about goods, and $63 \%$ of buyers make their purchase only at the sites providing reviews, ratings, comments and photos from the customers.

2 The free-of-charge basis and awareness of debt. Most people feel discomfort when they owe anybody money. It happens when a person gets something free-of charge. For online sales it refers to rendering a free-of-charge service. For example, Nova Poshta provides free delivery for regular customers.

3 The door-in-the-face technique. It refers to offering unsolicited goods at unreasonably high prices. $90 \%$ of offers are rejected, and only after that less costly products at reasonable prices are offered. 
4 The anxiety effect. The seller has to find the stimulus attractive for the client and, after that, "to activate" it. The information on limited amount of the product causes anxiety. For example: "Only two leopard Zara skirts are left".

5 The suggestion or placebo method. On the basis of the placebo effect the seller proves that this product will achieve a needed result. It works only when the customer is not an expert in the field; those proposing placebo should be thought leaders and the product should not be of importance for the customer ("not costly... why not try... even if it turns out to be useless...").

6 The technique: Pain - More pain - Hope - Solution [14]. Prospective clients must realize the understanding of their problems and eagerness to solve them. But nowadays such slogans are considered to be poor tactics: "You haven't lost your excess pounds? And only three days left before your journey?" That's a way to get a bad name. As the famous copywriter David Ogilvy said: "The customer is not a moron. She's your wife".

The research conducted made it possible to conclude the following. Despite a negative social opinion about neuromarketing techniques, today it is the only marketing activity which answers the question regarding the advertising/product the customer is expecting. And for the manufacturer it is the possibility to create "an ideal product and service" with the maximum efficiency level. But for the customer it is "the ideal satisfaction of wants". As far as neuromarketing is a new marketing technology, it is not actually formalized in legislation throughout the EU. Neuromarketing can have ethical and unethical techniques, as a majority of marketing methods. The advertising activity is regulated by the Consolidated ICC Code of Advertising and Marketing Communication Practice. Similarly, neuromarketing requires a legislative concept limiting unethical methods. Neuromarketing is a branch of medicine, and its motto must be of medical nature: "Primum non nocere" - "First, do no harm!"

\section{References}

1 About advertising and commercial market of Ukraine and the forecast for 2019. Available at: http://vrk.org.ua/ad-market (2018)

2 O.I. Zorina, O.V. Sivolovska, K.V. Zybina, I.M. Sivolovski, Vyperedzhajuchyj innovacijnyj rozvytok: teorija, metodyka, praktyka. Sumy: Trytorija. 404- 423, (2018)

3 A. Kislov. Forbes Available at: https://www.forbes.ru/tehnologii/352423-signal-mozgukak-neyromarketing-mozhet-izmenit-nashu-zhizn (2017)

4 Neuromarketing. Wikipedia. Available at: https://en.wikipedia.org/wiki/Neuromarketing

5 M. Oklander, Ju. Ghubarjeva.. Economist. Available at: http://uaekonomist.com/archive/2014/11/Oklander.Pdf (2014)

6 Gerald Zaltman, How Customers Think: Essential Insights into the Mind of the Markets Boston: Harvard Business School Press, (2003)

7 Martin Lindstrom, Buyology: Truth and Lies About Why We Buy Paperback. Currency, 272, (2010)

8 Global Neuromarketing Solutions Market: Snapshot. Available at: https://www.transparencymarketresearch.com

9 A. Traindl, Neuromarketing. Visualization of emotions. Alpina Business Book, (2007)

10 V. C. R. Fortunato, J. M. E. Giraldi, J. H. C. de Oliveira, Journal of Management Research, 6, 201-220 (2014)

11 D. Ariely, G. S. Berns, Nature Reviews Neuroscience, 11, 284-298 (2010)

12 C. Morin, Society, 48, 131-135 (2011)

13 David Ogilvy, Ogilvy on Advertising Paperback. Prion, (2007) 